\title{
Grafts containing human amniotic epithelial cells reduce hyperactivity in open-field and digital photo-actometer after Trimethyltin chloride lesion
}

\author{
K. V. Omprakash, ${ }^{1}$ R. Muthusamy, ${ }^{2}$ B. Devanand, ${ }^{3}$ Nagaraja Puranik, ${ }^{4}$ M. Mallikarjun ${ }^{5}$ \\ ${ }^{1}$ Department of Anatomy, Hassan Institute of Medical Sciences, Hassan, Karnataka, India; ${ }^{2}$ Department of Anatomy, \\ S.R.M. Dental College, Deemed University, Ramapuram, Chennai, India; ${ }^{3}$ Department of Anaesthesia, Vijayanagar Institute \\ of Medical Sciences, Bellary, Karnataka, India; ${ }^{4}$ Department of Physiology, Karnataka Institute of Medical Sciences,Hubli, \\ Karnataka, India. ${ }^{5}$ Department of Anatomy, Vijayanagar Institute of Medical Sciences, Bellary, Karnataka, India. \\ Correspondence to: Omprakash K.V, Department of Anatomy, Hassan Institute of Medical Sciences, Hassan 573 201, \\ Karnataka, India. Fax: 0091-081-72231699, Mobile: 0091-9449961209. \\ Email:drmprkshkv@gmail.com
}

\begin{abstract}
Introduction: The aim of present study is to provide adequate numbers of cells to appropriate sites for useful cellular replacement to overcome the functional deficits caused by the Trimethyltin chloride lesion.

Methods: The effect of Transplanted Human Amniotic Epithelial (HAE) cells in hippocampus after Trimethyltin chloride lesion was tested on Open-field activity and Digital Photoactometer during different time duration. Hippocampal disorder was induced by the intra peritoneal administration of Trimethyltin chloride (TMT) (Sigma chemicals, U.S.A) at a single dose of $7.5 \mathrm{mg} / \mathrm{kg}$ body weight or two divided doses of $3.75 \mathrm{mg} / \mathrm{kg}$ body weight for two days. Human Amniotic Epithelial cells were isolated from placenta obtained from uncomplicated elective caesarian. Using standard co-ordinates Human Amniotic Epithelial cells were transplanted at four sites of hippocampus.
\end{abstract}

Results: In present study, we observed that the transplanted Human Amniotic Epithelial cells can aid in the partial recovery of hyperactivity induced by the Trimethyltin chloride lesion in Open-field activity and Digital Photoactometer.

Conclusions: The present study concludes that the Human Amniotic Epithelial cells may be used as a suitable donor tissue to alleviate various degenerative diseases in animal model before the clinical trial in humans, who are suffering from various degenerative diseases.

Keywords: Digital photo-actometer, human amniotic epithelial cells, open field test, transplantation, trimethyltin chloride

\section{Introduction}

The striking disadvantage of a fully matured nervous system when compared to the other systems of the body is that the new nerve cells cannot be produced. So when neurons are lost due to anoxia or retrograde degeneration or due to some other reasons, there must be some alternatives. The usage of Human Amniotic Epithelial cells (HAE cells) as donor tissue for neuronal cellular replacement in cases of neurodegenerative diseases does not invoke any religious, ethical or legal issues like human fetal cortical tissue. Keeping all these points in mind we selected HAE cells as donor tissue for the replacement of cells in the Trimethyltin chloride (TMT) induced neurodegenerative disorder in the hippocampus of wistar albino rats. The rat hippocampus, after administration of the neurotoxin TMT, of fers a well- 
characterized model of neurodegeneration, with a distinct pattern of neuronal necrosis without appreciable demyelination, accompanied by a marked gliotic response. ${ }^{1}$

TMT is an organotin compound, intermediate by-product in the production of other tin compounds more commonly used in both industrial and agricultural settings, which is currently of interest more on account of its use as an experimental tool than in relation to environmental toxicology. ${ }^{2}$ Histological alterations are also associated with neurobehavioral changes, including severe learning and memory deficits, so that TMT has also been regarded as a potential tool for the study of memory dysfunction in animal models, including Alzheimer's disease. ${ }^{3,4}$ It produces the distinctive behavioral syndrome consisting of hyperactivity, seizures, learning disturbance and self-mutilation. The analysis of behavioral changes associated with brain damage in animals and humans is one of the oldest and most widely used methods in neurophysiology.

\section{Methods}

\section{Study population}

Wistar albino rats weighing $175 \pm 25$ g of either sex were used for the experiments. Animals were acclimatized to the animal house conditions (12:12 hr. light / dark cycle) for a week. Standard pelleted feed (Hindustan Lever Limited, Bangalore) and water were provided ad libitum (consumption of food and water by the animals as much as they want and when they wish). This project was approved by Institutional Animal Ethical Committee (IAEC). The project approval number is IAEC No. 01/011/03.

\section{Experimental Groups}

The animals were divided into three groups. Each group consists of six animals for six post operative periods of experiment. The groups were as follows.

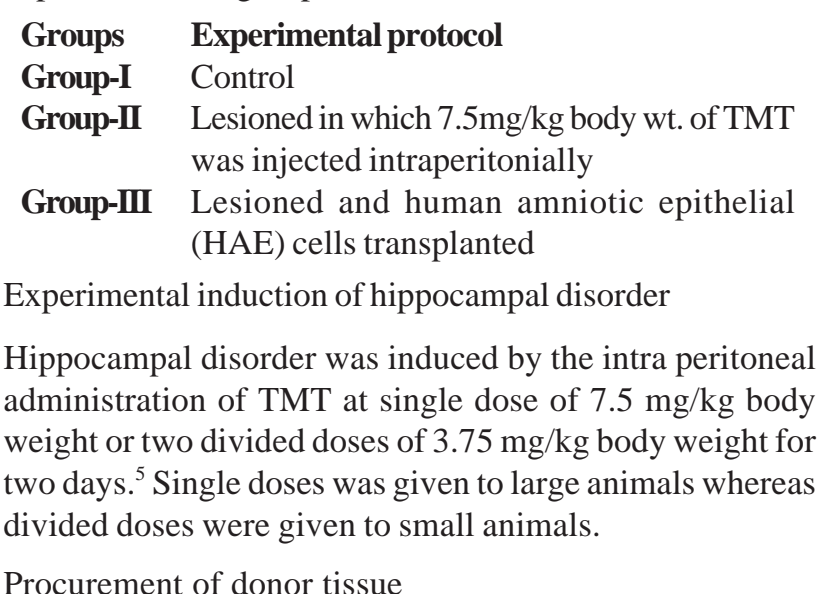

HAE cells to be transplanted were isolated from the fetal surface of the human placenta. Before collecting the specimens, necessary permissions were obtained from the Director of Medical Education, Government of Tamilnadu and the heads of the hospitals concerned. Placenta was collected from Durgabhai Deshmukh hospital, Chennai and from Govt. R.S.R.M.Lying-in Hospital, Chennai. Consent from the patient to donate the placenta for research purpose was also obtained. Human placenta, obtained from uncomplicated elective caesarian, was collected in a sterile container containing ice-cold lactated saline and transported to the laboratory within 30 minutes.

Isolation and culture of HAE cells

HAE cell isolation was done as described by Sakuragawa et al. ${ }^{6,7}$ The connective tissue from the amniotic membrane (AM) was scrubbed and removed. The membrane was then cleaned with Dextrose normal saline (DNS) thoroughly and trypsinised in $0.125 \%$ trypsin (Hi-media) in DNS for 3 changes of 20 minutes each. The pellets so obtained after each treatment were re-suspended in DNS and pooled together and washed in fresh DNS for 3 times. The HAE cells so obtained were suspended in RPMI 1640 culture medium with HEPES (Hydroxy ethyl piperazine sulphonic acid) buffer (Himedia India), supplemented with $10 \%$ fetal bovine serum. The HAE cells were then maintained in a carbon dioxide incubator in a humidified atmosphere of 5\% $\mathrm{CO}_{2}$ in air at $37^{\circ} \mathrm{C}$. The culture was maintained till the host animal was ready for transplantation.

Cell counting and viability test

Cell viability was done by trypan blue exclusion test at various time intervals during the culture. 0.5\% trypan blue was prepared by diluting $500 \mathrm{mg}$ of trypan blue dye in 100 $\mathrm{ml}$ of sterile normal saline adjusted to $\mathrm{pH} 7.2$ and kept as stock solution. One drop of donor tissue suspension was mixed with one drop of $0.5 \%$ trypan blue stock solution and one drop of saline on a clean microslide and covered with a coverslip. The dead cells were stained blue and the viable cells were unstained. The percentage of the viable cells was roughly estimated under microscope. The percentage of viability ranged from 90-95\%. Transplantation was done only if the viability was more than $85 \%$. The cells were flat and polygonal in shape with a dark and rounded nucleus in the center. The diameter of HAE cells varied from 4.5 to 6.5 microns (Fig: 1).

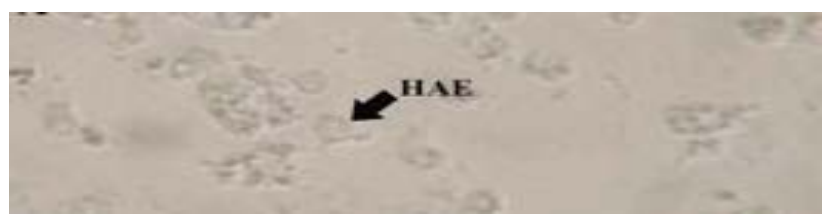

Fig. 1: Photomicrograph of human amniotic epithelial (HAE) cells in suspension stained with Tryphan blue (40X) 
Transplantation procedure

The animals to be transplanted were anesthetized using intra peritoneal injection of thiopentone sodium (Pentothal, Abbott Laboratories, India) at a dose of $40 \mathrm{mg} / \mathrm{kg}$ body weight and fixed in to a stereotaxic apparatus (Fig: 2). The plane of the incisor bar was set at $3.3 \pm 0.3 \mathrm{~mm}$ below the interaural line. After midline incision, the skull was exposed and four burr holes were drilled using standard coordinates for hippocampal transplantation. ${ }^{8}$ The coordinates include the following:

(i) anterior-posterior (AP) $=-3.3 \mathrm{~mm}$, posterior to bregma, lateral $(\mathrm{L})=2.5 \mathrm{~mm}$, and ventral $(\mathrm{V})=3.5 \mathrm{~mm}$ from the surface of brain; (ii) $\mathrm{AP}=-4.3 \mathrm{~mm}, \mathrm{~L}=3.5 \mathrm{~mm}$, and $\mathrm{V}=3.5 \mathrm{~mm}$. The syringe with a $26 \mathrm{G}$ needle, fitted to the electrode carrier of the stereotaxic apparatus and 5 to $10 \mu \mathrm{l}$ of cell suspension (2 $\mathrm{X} 10^{4}$ cells/ $\mu \mathrm{l}$ ) was slowly injected into the denervated hippocampus. After injecting the transplant, the needle was left in the place for 10 minutes and then withdrawn slowly. The surgical incision was closed in layeres. The animals were left undisturbed for two hours and then they were taken for post-operative management.

Antibiotic (Gentamycin 3 mg/kg/day) therapy was given till the wound heals. Initially we gave the immunosuppressant, cyclophosphamide at the dose of $5 \mathrm{mg} / \mathrm{kg}$ for 3 days for three animals on trial basis. As there were no differences between the immunosuppressed and nonimmunosuppressed animals in histological study, the entire study was conducted without any immunosuppressant.

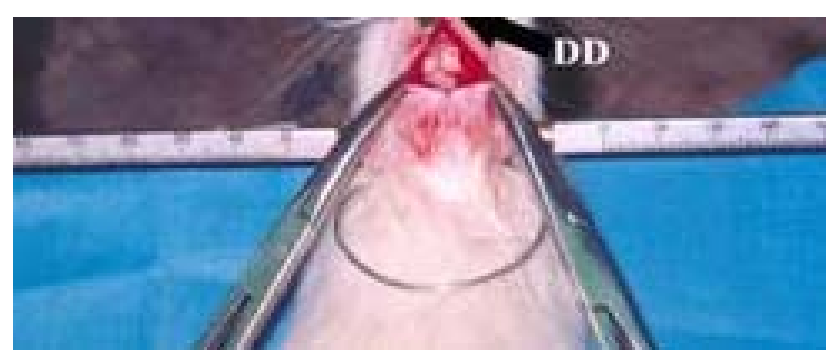

Fig. 2: Dental drill (DD) used to make a burr hole over the hippocampal area after fixation of the animal into the stereotaxic instrument

\section{Behavioral studies}

Rats were tested on a battery of behavioral tasks such as, Open field test and Digital photo-actometer.

Open field test(OFT) ${ }^{9}$

Open field activity was recorded in a 100 x $100 \mathrm{~cm}$ open plywood box with walls of $40 \mathrm{~cm}$ height. The floor of the box was divided into 25 equal squares by lines on the floor. A 100 Watts bulb was situated approximately 1.5 meter directly above the middle square. This was the only illumination used during testing. The test was carried out at least once in a week in each group between 09:00 and 17:00 hour, 7 days after the saline (control) injection, TMT treatments and transplantation procedures. The results of the tests obtained on $7^{\text {th }} 15^{\text {th }} 30^{\text {th }} 60^{\text {th }} 120^{\text {th }}$ and $150^{\text {th }}$ days were used for evaluation of the animals. At the beginning of the test each animal was placed in the center square of the open field, and observed for the next $5 \mathrm{~min}$. The following measures were taken: the number of (a) locomotion in peripheral squares ( defined as at least 2 paws entering a square), (b) locomotion in center squares, (c) times the animal reared on its hind legs, (d) bouts of grooming behavior and (e) fecal boli left in the open field (Fig: 3).

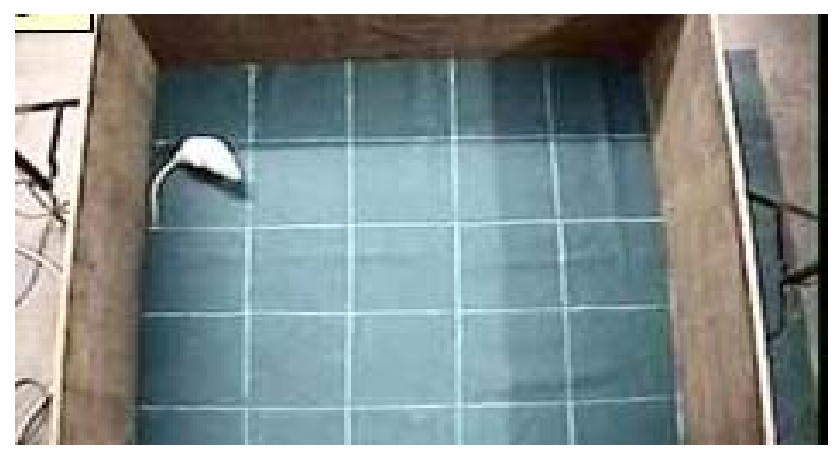

Fig. 3: The animal placed in the Open field test apparatus

Digital photo-actometer ${ }^{10}$

The digital photo-actometer (Dalal, India) is a closed cubical box measuring $34 \mathrm{~cm}$ in length, $35.5 \mathrm{~cm}$ in breadth and $10 \mathrm{~cm}$ in height in which the animal moves. The locomotor activity (horizontal activity) was measured in digital photo actometer which operates on photoelectric cells which are connected in circuit with a counter. When the beam of light falling on the photocell is cut off by the animal, a count is recorded. The movement of animal was recorded in this instrument for a period of 5 minutes (Fig: 4).

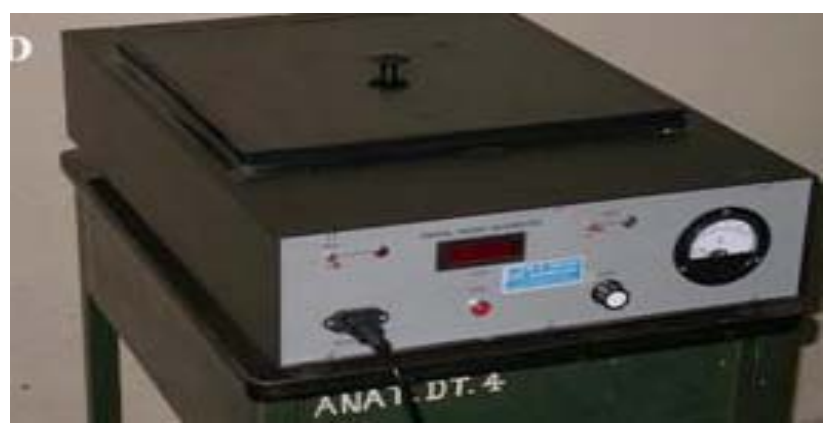

Fig. 4: Digital field actometer within which the animal is placed to record the locomoter activity 
Statistical Analysis

All the data were expressed as Mean \pm SEM and were analyzed by Analysis of Variance (ANOVA) followed by Tukey test and $\mathrm{P}$ values $<0.05$ were considered statistically significant.

\section{Results}

Open Field Test (OFT)

The results of the present study demonstrate that TMT produces time-related alterations in locomotor behavior in
Wistar albino rats. $7.5 \mathrm{mg} / \mathrm{kg}$ body weight of TMT produced hyperactivity which was most pronounced during the $15^{\text {th }}$ day after treatment with TMT. This hyperactivity persisted throughout the period of testing compared to the activity of the control animals. The peripheral square entries (square numbers) were increased from $7^{\text {th }}$ to $150^{\text {th }}$ days in group II over the group I. The significant increase in peripheral square entries was highest on $15^{\text {th }}$ day (64\%) and lowest on $120^{\text {th }}$ day $(12 \%)$ when compared to the control values. The group III animals showed decreased peripheral square entries which were maximum on $15^{\text {th }}$ day (35\%) and minimum on 120 th day (10\%) over the group II values (Table 1$)$.

Table 1: OFT- Peripheral square entries in the control, TMT lesioned and HAE cells transplanted animals from $7^{\text {th }}$ to $150^{\text {th }}$ day

\begin{tabular}{|c|c|c|c|c|c|c|}
\hline Group & $\mathbf{7}^{\text {th }}$ day & $\mathbf{1 5}^{\text {th }}$ day & $\mathbf{3 0}^{\text {th }}$ day & $\mathbf{6 0}^{\text {th }}$ day & $\mathbf{1 2 0}^{\text {th }}$ day & $\mathbf{1 5 0}^{\text {th }}$ day \\
\hline \multirow{2}{*}{ Group I } & $69.67 \pm$ & $67.83 \pm$ & $55.00 \pm$ & $51.83 \pm$ & $53.33 \pm$ & $45.67 \pm$ \\
& 3.65 & 2.70 & 2.82 & 2.76 & 0.71 & 1.63 \\
\hline \multirow{3}{*}{ Group II } & $105.33 \pm$ & $111.00 \pm$ & $77.33 \pm$ & $61.17 \pm$ & $59.67 \pm$ & $56.83 \pm$ \\
& 3.79 & 3.68 & 4.74 & 2.18 & 2.03 & 3.48 \\
& $\mathrm{a}^{* * *}$ & $\mathrm{a} * * *$ & $\mathrm{a} * * *$ & $\mathrm{a}^{*}$ & $\mathrm{a} *$ & $\mathrm{a} *$ \\
\hline \multirow{3}{*}{ Group III } & $71.00 \pm$ & $72.67 \pm$ & $57.50 \pm$ & $53.00 \pm$ & $53.67 \pm$ & $46.83 \pm$ \\
& 1.32 & 4.47 & 1.69 & 1.15 & 1.23 & 2.09 \\
& $\mathrm{a}^{\mathrm{NS}} \mathrm{b}^{* * *}$ & $\mathrm{a}^{\mathrm{NS}} \mathrm{b}^{* * *}$ & $\mathrm{a}^{\mathrm{NS}} \mathrm{b}^{* *}$ & $\mathrm{a}^{\mathrm{NS}} \mathrm{b}^{*}$ & $\mathrm{a}^{\mathrm{NS}} \mathrm{b}^{*}$ & $\mathrm{a}^{\mathrm{NS}} \mathrm{b}^{*}$ \\
\hline
\end{tabular}

Mean \pm SEM. $\quad(\mathrm{N}=6) . \quad$ a - Group I Vs II \& III; $\quad$ b-Group II Vs III; $\quad$ NS- not significant. $\mathrm{P} \leq 0.001 * * * ; \mathrm{P} \leq 0.01 * * ; \mathrm{P} \leq 0.05 *$.

Table 2: OFT- Central square entries in the control, TMT lesioned and HAE cells transplanted animals from $7^{\text {th }}$ to $150^{\text {th }}$ day

\begin{tabular}{|c|c|c|c|c|c|c|}
\hline Group & $\mathbf{7}^{\text {th }}$ day & $\mathbf{1 5}^{\text {th }} \mathbf{d a y}$ & $\mathbf{3 0}^{\text {th }} \mathbf{d a y}$ & $\mathbf{6 0}^{\text {th }} \mathbf{d a y}$ & $\mathbf{1 2 0}^{\text {th }} \mathbf{d a y}$ & $\mathbf{1 5 0}^{\text {th }} \mathbf{d a y}$ \\
\hline Group I & $19.67 \pm 1.50$ & $18.83 \pm 1.19$ & $20.00 \pm 1.98$ & $15.50 \pm 1.06$ & $12.33 \pm 0.71$ & $10.00 \pm 0.58$ \\
\hline Group II & $\begin{array}{c}11.83 \pm 0.70 \\
\mathrm{a}^{* * *}\end{array}$ & $\begin{array}{c}8.17 \pm 0.83 \\
\mathrm{a}^{* * *}\end{array}$ & $\begin{array}{c}9.50 \pm 0.72 \\
\mathrm{a}^{* * *}\end{array}$ & $\begin{array}{c}5.17 \pm 1.14 \\
\mathrm{a}^{* * *}\end{array}$ & $\begin{array}{c}5.83 \pm 0.31 \\
\mathrm{a}^{* * *}\end{array}$ & $\begin{array}{c}6.17 \pm 0.31 \\
\mathrm{a} * * *\end{array}$ \\
\hline Group III & $\begin{array}{c}16.83 \pm 1.01 \\
\mathrm{a}^{\mathrm{NS}} \mathrm{b}^{*}\end{array}$ & $\begin{array}{c}16.67 \pm 0.80 \\
\mathrm{a}^{\mathrm{NS}} \mathrm{b}^{* * *}\end{array}$ & $\begin{array}{c}17.50 \pm 0.43 \\
\mathrm{a}^{\mathrm{NS}} \mathrm{b}^{* * *}\end{array}$ & $\begin{array}{c}14.00 \pm 0.52 \\
\mathrm{a}^{\mathrm{NS}} \mathrm{b}^{* * *}\end{array}$ & $\begin{array}{c}10.00 \pm 0.89 \\
\mathrm{a}^{\mathrm{NS}} \mathrm{b}^{* *}\end{array}$ & $\begin{array}{c}9.00 \pm 0.73 \\
\mathrm{a}^{\mathrm{NS}} \mathrm{b}^{* *}\end{array}$ \\
\hline
\end{tabular}

Mean \pm SEM. $\quad(\mathrm{N}=6) . \quad$ a - Group I Vs II \& III; $\quad$ b-Group II Vs III; $\quad$ NS- not significant. $\mathrm{P} \leq 0.001 * * * ; \mathrm{P} \leq 0.01 * * ; \mathrm{P} \leq 0.05^{*}$ 
There was a significant reduction in the central square entries for lesioned group with respect to the control group ( $7^{\text {th }}$ day $40 \%, 15^{\text {th }}$ day $57 \%, 30^{\text {th }}$ day $53 \%, 60^{\text {th }}$ day $67 \%, 120^{\text {th }}$ day $53 \%$ and $150^{\text {th }}$ day $38 \%$ ). Maximum reduction was observed on $60^{\text {th }}$ day $(67 \%)$ and minimum reduction was observed on $150^{\text {th }}$ day (38\%). The group III animals showed increased central square entries when compared with group II animals ( $7^{\text {th }}$ day $42 \%, 15^{\text {th }}$ day $104 \%$, 30 $0^{\text {th }}$ day $84 \%$, $60^{\text {th }}$ day $171 \%, 120^{\text {th }}$ day $72 \%$ and $150^{\text {th }}$ day $46 \%$ ), which were maximum on $60^{\text {th }}$ day (171\%) and minimum on $7^{\text {th }}$ day (42\%) (Table 2).

The control rats moved all over the field while most of the TMT treated rats moved round along the edge of the field indicating that TMT produced an increase in the pattern of activity rather than an increase in exploration.

There were no significant differences between the control, TMT lesioned and Lesioned and HAE cells transplanted groups in the grooming, rearing and defecation pattern.

\section{Digital photo-actometer}

In the present study the locomotor activity of all the three groups for a period of 5 minutes duration was observed in the dark environment. The group I animals showed increased movements in the beginning of the experiment and got reduced at the end of the experiment. The ranges of activity were from $159.50 \pm 1.66$ to $91.83 \pm 2.66$ for group I. In group II animals the number of activity ranged from 244.67 \pm 2.53 to $148.33 \pm 2.60$. The group II animals showed significant increase in motor activity in the digitalphotactometer in all the duration of study when compared with control animals (Pd”0.001). However the HAE cells transplanted group showed reduction in motor activity when compared to the TMT lesioned animals $\left(29 \%\right.$ on $7^{\text {th }}$ day; $37 \%$ on $15^{\text {th }}$ day; $31 \%$ on $30^{\text {th }}$ day; $28 \%$ on $60^{\text {th }}$ day; $27 \%$ on $120^{\text {th }}$ day and $33 \%$ on $150^{\text {th }}$ day) (Table 3 ).

\section{Discussion}

\section{Open field test (OFT)}

In this test, the locomotor activity and the sensory motor deficits of the animals, after TMT treatment and recovery after the HAE cells transplantation in the hippocampus of Wistar albino rats were observed. Locomotor activity was measured as total ambulation time, which showed how far the animals moved forward and or in lateral direction with their trunk in horizontal position, lifting and placing each limb during five minutes with the modification of Oosten and Cools. ${ }^{11}$ A consistently reported consequence of TMT exposure has been hyperactivity observed in the openfield. ${ }^{12,13}$ The results of the present study confirm these observations and also address the time-dependent nature of the phenomenon.

The control rats moved all over the field while most of the TMT treated rats moved round along the edge of the field indicating that TMT produced an increase in the pattern of activity rather than an increase in exploration. This result supports the previous work of Ruppert et al . ${ }^{14}$

Grooming and rearing are sensory motor function of the rodents. In the present study we observed the number of grooming and rearing of the animals for five minutes. There were no significant differences between the control, TMT lesioned and lesioned and HAE cells transplanted groups in the grooming, rearing and defecation pattern. These results are in line with the results obtained by Craig et al ${ }^{15}$

\section{Digital photo-actometer}

In the present study, locomotor activity of the TMT treated animals for 5 minutes duration was observed in the digital photo-actometer. The increased neuronal activity observed after TMT treatment might be due to either the potentiation of excitatory glutamate transmissions or the attenuation of

Table 3. Mobilization status of the control, TMT lesioned and HAE cells transplanted animals from $7^{\text {th }}$ to $150^{\text {th }}$ day in Digital photo-actometer.

\begin{tabular}{|c|c|c|c|c|c|c|}
\hline Group & $\mathbf{7}^{\text {th }}$ day & $\mathbf{1 5}^{\text {th }}$ day & $\mathbf{3 0}^{\text {th }}$ day & $\mathbf{6 0}^{\text {th }}$ day & $\mathbf{1 2 0}^{\text {th }}$ day & $\mathbf{1 5 0}^{\text {th }}$ day \\
\hline Group I & $159.50 \pm 1.66$ & $152.83 \pm 2.49$ & $148.33 \pm 1.61$ & $118.00 \pm 0.97$ & $94.33 \pm 2.05$ & $91.83 \pm 2.66$ \\
\hline Group II & $\begin{array}{c}229.83 \pm 3.42 \\
\mathrm{a}^{* * *}\end{array}$ & $\begin{array}{c}244.67 \pm 2.53 \\
\mathrm{a}^{* * *}\end{array}$ & $\begin{array}{c}219.50 \pm 3.75 \\
\mathrm{a} * * *\end{array}$ & $\begin{array}{c}168.50 \pm 2.04 \\
\mathrm{a} * * *\end{array}$ & $\begin{array}{c}154.83 \pm 2.59 \\
\mathrm{a} * * *\end{array}$ & $\begin{array}{c}148.33 \pm 2.60 \\
\mathrm{a} * * *\end{array}$ \\
\hline Group III & $\begin{array}{c}162.17 \pm 2.33 \\
\mathrm{a}^{\mathrm{NS}} \mathrm{b}^{* * *}\end{array}$ & $\begin{array}{c}153.33 \pm 2.90 \\
\mathrm{a}^{\mathrm{NS}} \mathrm{b}^{* * *}\end{array}$ & $\begin{array}{c}151.17 \pm 2.85 \\
\mathrm{a}^{\mathrm{NS}} \mathrm{b}^{* * *}\end{array}$ & $\begin{array}{c}121.33 \pm 1.94 \\
\mathrm{a}\end{array}$ & $\begin{array}{c}113.00 \pm 3.41 \\
\mathrm{~N}^{* * *} \mathrm{~b}^{* * * *}\end{array}$ & $\begin{array}{c}99.17 \pm 4.38 \\
\mathrm{a}^{\mathrm{NS}} \mathrm{b}^{* * * *}\end{array}$ \\
\hline
\end{tabular}


the inhibitory GABAergic system. ${ }^{16}$ TMT is reported to cause inhibition in glutamate uptake increased extracellular concentration of glutamate and increased release of glutamate in vitro. ${ }^{17-19}$ TMT exposure is, on the other hand, reported to reduce the concentration of GABA, leading to decreased inhibition to dentate granule cells. ${ }^{3,20}$ Another possibility to interpret the mechanism underlying increased excitability in TMT treated rats is the involvement of peptidergic neurons. ${ }^{16}$ The HAE cells transplanted animals showed locomotor activity near to that of control animals. The attenuation of hyperactivity observed in the study might be due to neurotrophic factors secreted by the graft and restoration of neuronal circuit in the denervated hippocampus.

\section{Conclusions}

Intraperitoneal administration of TMT produces severe and permanent damage in the hippocampus and can be used as a suitable model for hippocampal disorder. Secondly, the overall improved performance of HAE cells treated group from the TMT lesioned group in the OFT and digital photoactometer could indicate that the HAE cells could be used as a suitable donor tissue to alleviate various neurodegenerative diseases in animal model and this knowledge can be utilized for the clinical trial in humans, who are suffering from various neurodegenerative diseases.

\section{Acknowledgement}

We thank Dr. S.R. Hegde, former Director of VIMS; Bellary, Karnataka, India who was instrumental in granting the required permission to take up this research work. We gratefully acknowledge Dr. Arun Kumar.S. Bilodi, Professor and H.O.D, Department of Anatomy, Hassan Institute of Medical Sciences, Hassan, Karnataka, India for the suggestions given by him to prepare this paper.

\section{References}

1. Geloso MC, Vinesi P, Michetti F. Calretinin-containing neurons in trimethyltin-induced neurodegeneration in the rat hippocampus: an immunocytochemical study. Experimental Neurology 1997;146:67-73.

2. Koczyk D. How does trimethyltin affect the brain: Facts and hypothesis. Acta Neurobiology Exp. 1996;56:587-96.

3. Early B, Burke M, Leonard BE. Behavioural, biochemical and histological effects of Trimethyltin induced brain damage in the rat. Neurochemistry International 1992;21:351-66.
4. Woodruff ML, Baisden RH. Trimethyltin neurotoxicity in the rat as an analogous model of Alzheimer's disease. In:Woodruff ML, Nonnemann AJ, editors. Toxin-induced models of neurological disorders. New York : plenurm; 1994.p.319-35.

5. Roy A, Agrawal AK, Husain R, Dubey MP, Seth PK. (1999). Cholinergic and serotonergic alterations in the rat hippocampus following trimethyltin exposure and fetal neural transplantation. Neuroscience Letters 1999;259:173-6.

6. Sakuragawa N, Thangavel R, Mizuguchi M, Hirasawa M, Kamo I. Expression of markers for both neuronal and glial cells in human amniotic epithelial cells. Neuroscience Letters 1996;209:9-12.

7. Sakuragawa N, Misawa H, Ohsugi K, Kakishita K, Ishii T, Thangavel R. Evidence for active acetylcholine metabolism in human amniotic epithelial cells: applicable to intracerebral allografting for neurologic disease. Neuroscience Letters 1997;232:53-6.

8. Shetty AK, Turner DA. Enhanced cell survival in fetal hippocampal suspension transplants grafted to adult rat hippocampus following kainate lesions. Neuroscience 1995;67:561-82.

9. Dunnet SB, Low WC, Iversen SD, Stenevi U, Bjorklund A. Septal transplants restore maze learning in rats with fornix-fimbria lesions. Brain Research 1982;251:335-48.

10. Goyal RK. Practicals in pharmacology. 4th ed. Ahamadabad, India; B.S. Shah Prakashan; 2003-2004.

11. Oosten VRV, CoolsAR. Differential effects of a small, unilateral 6-hydroxydopamine induced nigral lesion on behaviour in high and low responders to novelty. Experimental Neurology 2002;178:245-55.

12. Tsutsumi S, Akaike M, Arimitsu H, Imai H, Kato N. Circulating corticosterone alters the rate of neuropathological and behavioral changes induced by trimethyltin in rats. Experimental Neurology 2002;173:86-94.

13. Woodruff ML, Baisden RH, Whittington DL, Shelton NL, Wray S. Grafts containing fetal hippocampal tissue reduce activity and improve passive avoidance in hippocampectomized or trimethyltin-exposed rats. Experimental Neurology 1988;102:130-43.

14. Ruppert PH, Walsh TJ, Reiter LW, Dyer RS. 
Trimethyltin-induced hyperactivity: time course and pattern. Neurobehave Toxicol Tratol 1982;4:135-9.

15. Craig TJ, Dunn A, Carole R, Thomas JW, Swartzwelder HS. Alterations in regulatory and locomotor behaviors following trimethyltin exposure in the rat: a time and dose analysis. Neuroscience letters 1984;47:99-106.

16. Ishida N, Akaike M, Tsutsumi S, Kanai H, Masui A, Sadamatsu M, et al. Trimethyltin syndrome as a hippocampal degeneration model: temporal changes and neurochemical features of seizure susceptibility and learning impairment. Neuroscience 1997;81: 1183-91.

17. Naalsund LU, Allen CN, Fonnum F. Changes in neurobiological parameters in the hippocampus after exposure to Trimethyltin. Neurotoxicology 1985;6:145-58.

18. Lipe GW, Ali SF, Newport GD, Scallet AC, Slikker W.Jr. Effect of Trimethyltin on amino acid concentrations in different regions of the mouse brain. Pharmac. Toxicol.1991;68:450-5.

19. Patel M,Ardelt BK, Yim GK, Isom GE. Interaction of Trimethyltin with hippocampal glutamate. Neurotoxicology 1990;11:601-8.

20. Mailman RB, Krigman MR, Frye GD, Hanin I. Effects of postnatal Trimethyltin or triethyltin treatment on CNS catecholamine, GABA and acetylcholine systems in the rat. Journal of Neurochemistry 1983;40:1423-9. 